Kumawula, Vol. 3, No.1, April 2020, Hal 106 - 115 DOI:http://10.24198/kumawula.v3i1.24588

ISSN 2620-844X (online)

Tersedia online di http://jurnal.unpad.ac.id/kumawula/issue/view

\title{
PENDEKATAN ACTIVE CITIZEN DALAM PEMETAAN MASALAH TERKAIT DAERAH ALIRAN SUNGAI (DAS) CITARUM DI DESA SINDANGPAKUON
}

\author{
Adhi Alfian $^{1 *}$, Raihan Farid Rachmaditya ${ }^{2}$, Risa Marliyana ${ }^{3}$, Shindy Apriliany ${ }^{4}$, \\ Dudi Adiansyah ${ }^{5}$ \\ 1,2,3,4,5 Universitas Padjadjaran \\ *adhi.alfian@unpad.ac.id
}

\begin{abstract}
ABSTRAK
Permasalahan Daerah Aliran Sungai (DAS) Citarum sudah sangat kompleks, mencakup permasalahan di hulu sampai ke hilir, beberapa permasalahan terkait dengan lahan kritis, konservasi air, pengelolaan sampah domestik dan limbah agro, sanitasi lingkungan, sampai bencana alam. Perlu dilakukan akselerasi untuk mengatasi permasalahan tersebut, pemerintah sudah berinisiatif membuat program Citarum Harum, yang merupakan proyek kolaborasi antara pemerintah pusat dan daerah dengan tujuan membuat Sungai Citarum dan seluruh alirannya dapat menjadi sungai terbersih di dunia suatu saat nanti. Namun upaya tersebut tidak bisa hanya dilakukan oleh pemerintah, perlu partisipasi aktif dari berbagai lapisan masyarakat, akademisi, media, swasta, dan lainnya. Salah satu yang utama tentu saja peran aktif masyarakat yang dialiri oleh DAS Citarum. Masyarakat setempat harus dilibatkan dalam analisis masalah sampai perumusan solusi masalah DAS Citarum ini, sehingga pada akhirnya mereka akan menjadi ujung tombak upaya menormalisasi DAS Citarum. Pendekatan active citizen dianggap tepat digunakan dalam proses analisis permasalahan ini, pendekatan ini menekankan dialog budaya dan sosial yang titik tumpunya ada di masyarakat. Berdasarkan analisis yang telah dilakukan diketahui bahwa masalah pengelolaan sampah merupakan akar masalah utama yang berdampak pada berbagai masalah lain dan harus menjadi prioritas penanganan. Berdasarkan perumusan solusi masalah yang dilakukan terdapat lima rumusan solusi untuk menghadapi masalah tersebut.
\end{abstract}

Kata Kunci: Active Citizen; Daerah Aliran Sungai; Citarum; Pemetaan Masalah; Sindangpakuon

\section{Pendahuluan}

Sungai Citarum merupakan sungai terbesar di Jawa Barat dengan luas total area 11.437 $\mathrm{km}^{2}$ (BPS Jawa Barat, 2018), memiliki peran yang sangat signifikan untuk kehidupan masyarakatnya. Fungsi hidrologis dari Sungai Citarum adalah menampung curah air hujan yang jatuh di Daerah Aliran Sungai (DAS)-nya dan mendistribusikan ke seluruh wilayah alirannya. Limpasan air permukaan Citarum secara keseluruhan mencapai 16.713,1 juta meter kubik per tahun. Masing-masing terbagi menjadi limpasan di wilayah hulu sebesar 4.001 juta meter kubik, wilayah tengah sebesar 5.259 meter kubik, dan 7.453 meter kubik di wilayah hilir. Menurut Nurfatriani \& Nugroho (2008) Citarum setidaknya memberikan nilai manfaat 
secara ekonomi sebesar Rp.1,6 triliun per tahun hanya untuk sektor pertanian disekitarnya saja (LIPI, 2019).

Sungai Citarum berperan sangat besar dan penting, namun perhatian berbagai pihak atas kelestarian lingkungan DAS Citarum sangat buruk sekali. Beberapa masalah pada DAS Citarum antara lain terkait dengan lahan kritis, konservasi air, pengelolaan sampah domestik dan limbah agro, sanitasi lingkungan, dan bencana alam (Unpad, 2019).

Upaya perbaikan DAS Citarum membutuhkan proses yang cukup panjang, karena sungai Citarum dan daerah sekitar alirannya telah tercemar puluhan tahun. Bahkan World Bank sejak satu dekade yang lalu sudah menyatakan bahwa Citarum adalah sungai terkotor di dunia. Permasalahan DAS Citarum pada dasarnya karena pertumbuhan penduduk yang tidak terkendali, kemudian berdampak peningkatan eksploitasi ruang dan sumber daya air. Disamping itu, peningkatan pertumbuhan penduduk dan industri di wilayah DAS Citarum tidak diiringi dengan sistem pengelolaan limbah yang baik sehingga mengakibatkan pencemaran lingkungan yang tinggi (Pemprov Jabar, 2019).

Generasi berganti, pemerintahan berubah, kondisi DAS Citarum tidak semakin baik. Baru pada era pemerintahan Presiden Jokowi, sebuah langkah penanggulangan diambil. Melalui Peraturan Presiden Nomor 15 Tahun 2018 tentang Percepatan Pengendalian Pencemaran dan Kerusakan Daerah Aliran Sungai Citarum, pemerintah berkomitmen untuk melakukan langkah-langkah perbaikan pada DAS Citarum.

Untuk merealisasikan tujuan yang sudah dicanangkan tersebut, pemerintah membuat program kolaborasi dalam bingkai program Citarum Harum, yang ditargetkan selama tujuh tahun sungai Citarum dapat menjadi sungai terbersih di dunia. Pelaksanaan program ini dipimpin Komandan Satuan Tugas yaitu Gubernur Jawa Barat. Sementara Wakil Komandan Satuan Tugas dipegang Panglima Kodam III/Siliwangi, artinya tentara terlibat langsung dalam pelaksanaannya. Sebanyak 1.700 personel TNI diterjunkan untuk menjaga dan mengawasi Sungai Citarum yang dibagi ke dalam 22 sektor (Pemprov Jabar, 2019).

Program Citarum Harum memiliki tiga strategi utama yaitu meliputi langkah struktural, non struktural, dan kultural. Langkah struktural meliputi pembuatan tanggul sungai secara optimal, normalisasi aliran sungai dengan mengurangi sedimentasi dan pembuatan drainase di sepanjang jalan yang dilalui Citarum. Langkah non struktural yaitu membuat sumur resapan dengan penerapan kebijakan zero run-off oleh setiap pembuat bangunan, pembuatan water treatment oleh perusahaan penghasil limbah dan pengawasan dan law enforcement terhadap 
para pembuang limbah ke Citarum. Kemudian pola pendekatan kultural meliputi membudayakan buang sampah pada tempatnya.

Desa Sindangpakuon merupakan salah satu wilayah yang dilalui DAS Citarum, dimana terdapat 4 Sub Daerah Aliran Sungai (SUBDAS) Citarum yang melewati desa, yaitu sungai Cimande, sungai Ciburaleng, sungai Ciranjeng dan sungai Citarik merupakan salah satu objek yang perlu mendapat perhatian dalam upaya menanggulangi permasalahan DAS Citarum (Profil Desa, 2019). Universitas Padjadjaran sebagai salah satu stakeholder dalam konteks Pentahelix, merasa berkewajiban dalam membantu permasalahan DAS Citarum di Desa Sindangpakuon, khususnya terlibat dalam upaya penanganan secara kultural dengan target meningkatkan kepedulian dan kesadaran masyarakat setempat. Upaya yang dilakukan tersebut dalam bentuk pelaksanaan program KKN Tematik Citarum Harum di desa Sindangpakuon. Adapun tujuan umum kegiatan KKN Tematik ini adalah: memberdayakan individu dan masyarakat sebagai kelompok sasaran, khususnya di bidang lingkungan hidup, yang dikaitkan dengan peningkatan mutu sosial-ekonomi kemasyarakatan melalui program dan kegiatannya; mengenalkan dinamika permasalahan, isu-isu, dan keberagaman kondisi sosial-budaya masyarakat sebagai sumber pembelajaran eksternal mahasiswa; meningkatkan empati dan kepedulian mahasiswa secara langsung dengan kehidupan masyarakat. Metode yang digunakan dalam program dimaksud berbasis Active Citizen.

\section{Metode}

Kegiatan pemetaan masalah terkait Daerah Aliran Sungai (DAS) Citarum di Desa Sindangpakuon menggunakan metode active citizen. Metode active citizen adalah suatu pendekatan kepemimpinan sosial yang mempromosikan dialog antar budaya dan pembangunan sosial yang diinisiasi oleh masyarakat. Metode ini dapat dilakukan dalam beberapa cara bergantung pada keadaan lingkungan dan sumber daya yang dimiliki, dari yang bersifat formal seperti di dalam kelas, sampai yang non-formal seperti di dalam rumah, halaman kebun, dan lain sebagainya. Pendekatan active citizen merupakan sebuah pendekatan global yang telah digunakan di lebih dari 46 negara, melibatkan sekitar 525 organisasi mitra dan 155.000 masyarakat aktif yang membuat 6.232 program sosial (British Council, 2016). Beberapa program yang sudah dilakukan diantaranya merupakan program pemberdayaan daerah aliran sungai seperti yang saat ini dibutuhkan pada DAS Citarum

Pada pelaksanaan kegiatan KKN Tematik DAS Citarum di Desa Sindangpakuon, metode ini digunakan sebagai media dialog yang melibatkan sebanyak mungkin stakeholder di Desa 
Sindangpakuon yang terdari unsur masyarakat, pemerintah desa, aparat kepolisian dan TNI, Satgas Citarum Harum, media massa, dan unsur lainnya, dimana dosen dan mahasiswa bertindak sebagai fasilitator untuk menampung dan menyalurkan arah dialog untuk dapat menyelesaikan permasalahan terkait DAS Citarum.

Kegiatan ini didahului dengan kegiatan observasi lapangan oleh para fasilitator dengan cara melakukan perjalanan menyusuri setiap dusun yang ada di Desa Sindangpakuon. Dalam setiap dusun yang dikunjungi, tim fasilitator bertemu dengan setiap Kepala Dusun, Ketua RW, dan masyarakat yang ada untuk menanyai kondisi dan permasalahan yang ada di lingkungan sekitar. Observasi dilakukan untuk mengetahui kondisi Desa Sindangpakuon secara komprehensif. Dengan dilakukannya observasi, fasilitator mengetahui berbagai kondisi dasar seperti topografi wilayah; struktur pengelola kewilayahan; keadaan ekonomi, sosial, budaya; kelebihan dan kekurangan yang dimiliki; pola interaksi antar masyarakat; dan aspek lainnya.

Tahap selanjutnya yang dilakukan adalah menuangkan hasil observasi dan dialog kedalam 4 bentuk canvas yang telah ditentukan. Penggunaan canvas ini dimaksudkan agar proses berfikir atas suatu masalah dikembangkan secara sistematik, mulai dari kondisi masyarakat, lingkungan, kelebihan dan kekurangan, inti masalah, sampai kepada solusi yang ditawarkan. Berdasarkan hasil pemetaan awal yang telah dilakukan oleh tim fasilitator pada kegiatan sebelumnya, telah dipilih lima tema utama terkait dengan permasalahan DAS Citarum yang akan dianalisis lebih dalam. Kelima tema tersebut terdiri dari: 1) Keberadaan Lahan Kritis, 2) Konservasi Air, 3) Pengelolaan Sampah Domestik dan Limbah Agro, 4) Sanitasi Lingkungan, 5) Risiko dan Mitigasi Bencana.

Adapun secara lebih lengkap 4 canvas yang digunakan terdiri dari (Unpad, 2019): 1) Canvas Pohon Masalah, dalam canvas tersebut dituliskan akar-akar masalah yang ada secara umum kemudian akibat dari masalah tersebut dan solusi yang bisa diberikan terhadap masalah yang ada. 2) Canvas Teori Persona, dalam canvas tersebut dituliskan kebiasaan negatif dan kebiasaan positif yang dilakukan masyarakat sekitar serta menyimpulkan apa yang sebenarnya masyarakat butuhkan dan inginkan. 3) Canvas System Thinking, dalam canvas tersebut terdapat gambaran gunung es, dimana diinterpretasikan pada ujung gunung adalah masalah umum yang terjadi kemudian semakin kebawah semakin melebar sehingga bagian bawah gunung es menjelaskan apa yang menyebabkan masalah diatasnya terjadi hingga pada dasar gunung es dapat diketahui penyebab utama atau akar masalah yang terjadi. 4) Canvas terakhir adalah canvas Teori Perubahan, dalam canvas tersebut terdapat 6 proses yang diawali 
dari perumusan masalah yang ada sampai solusi kemudian hasil dan dampak yang diharapkan dari solusi yang diberikan. Dibawah ini adalah 4 jenis canvas yang digunakan dalam pelaksanaan pemetaan masalah DAS Citarum di Desa Sindangpakuon:

Pohon Masalah
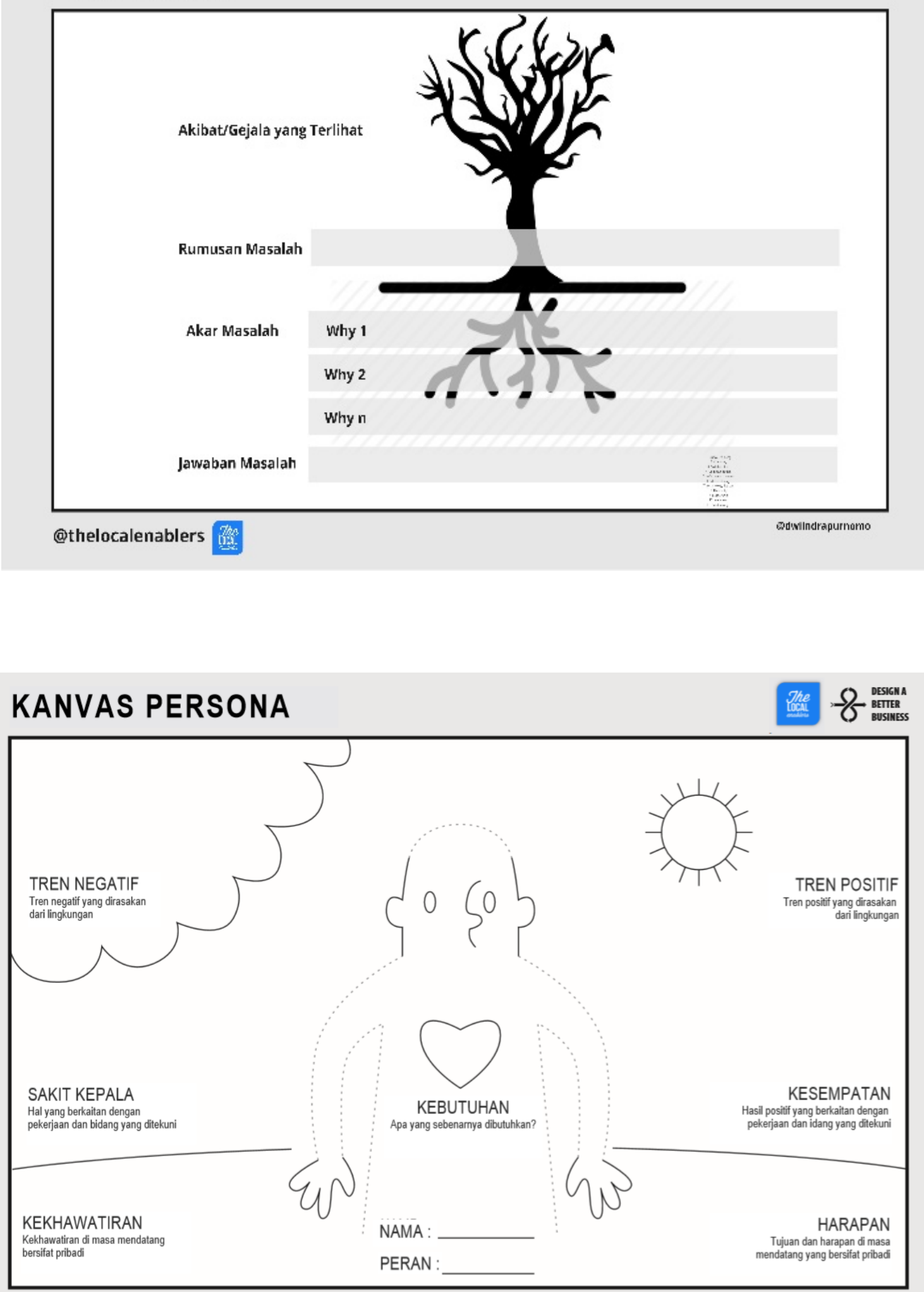
Leverage Point (System Thinking)

बirund

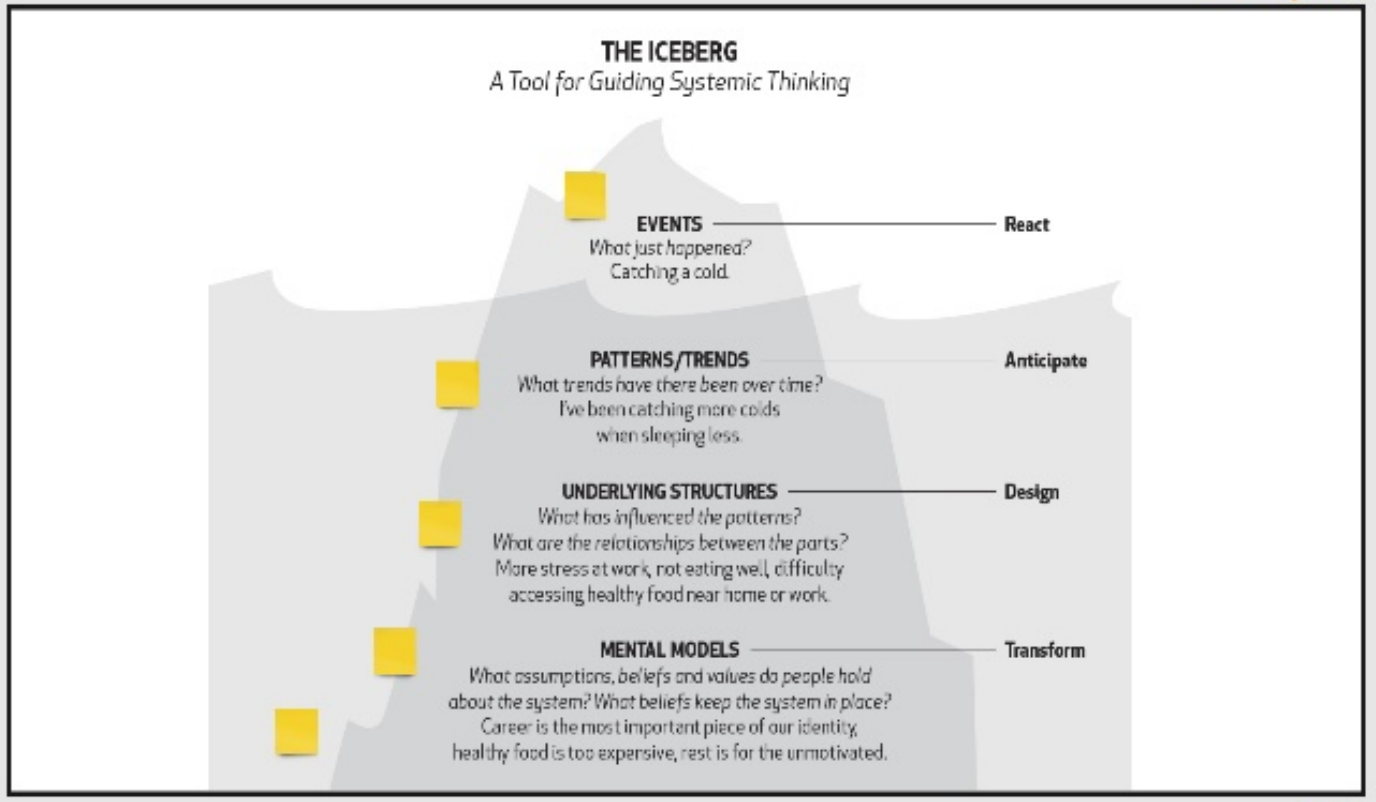

@thelocalenablers

Teorl Perubahan (Theory of Change)

@thelocalenablers

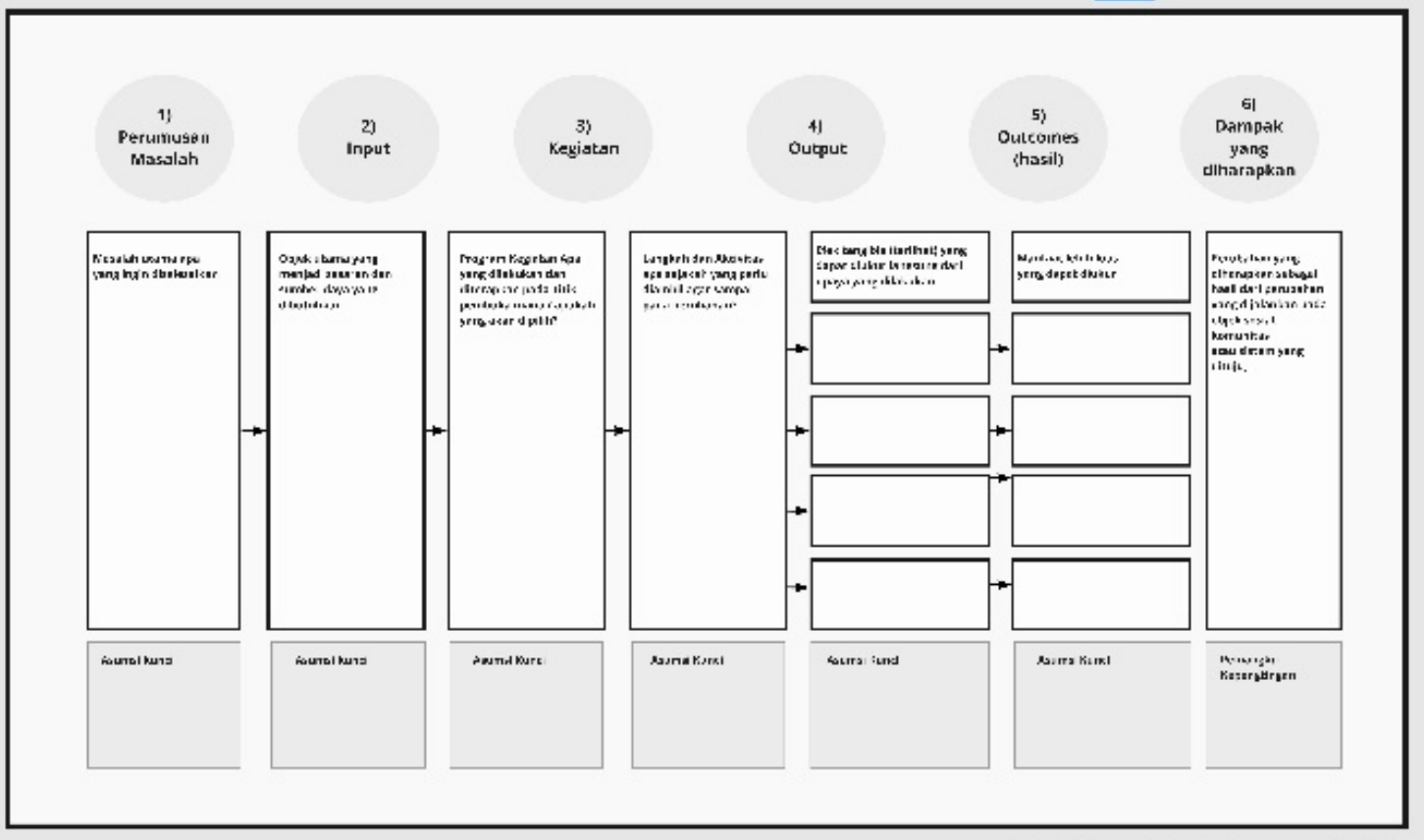

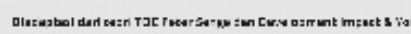

Gambar 1. Canvas Pemetaan Masalah DAS Citarum di Desa Sindangpakuon (Unpad, 2019)

Tahap selanjutnya setelah dilakukan penggambaran permasalahan secara sistematis, fasilitator mengundang pihak-pihak terkait untuk mendiskusikan rumusan yang sudah dibuat. Proses dialog dilakukan secara bertahap yaitu pertama dilakukan kepada aparat desa dalam momen musyawarah desa, kedua dilakukan kepada perwakilan masyarakat yang dalam hal ini 
dilakukan dengan perwakilan RW 12, masyarakat RW 12 dapat dikatakan sebagai masyarakat paling aktif di Desa Sindangpakuon karena sudah memiliki organisasi dan program rutin dalam kaitannya dengan upaya penanggulangan masalah di sekitar DAS Citarum. Dialog ketiga dilakukan dengan Satgas Citarum Harum sektor 21 subsektor 15, dialog ini lebih menitikberatkan kepada rencana aksi yang akan dilakukan yaitu upaya kerja bakti.

Tahap selanjutnya yaitu membuat piloting (percontohan) program aksi sesuai dengan hasil dialog yang telah dilakukan. Adapun program aksi yang telah dilakukan terdiri dari: kerja bakti, sosialisasi di SD Parakanmuncang 1 dan 2, pelaksanaan pembuatan budidaya keramba ikan nila, senam sosialisasi cuci tangan bersama warga RW 08, dan terakhir ramah tamah dan kegiatan keakraban dengan warga dengan cara dialog, makan bersama, dan mengopi bersama.

\section{Hasil dan Pembahasan}

\subsection{Analisis Permasalahan}

Berdasarkan hasil analisis yang telah dilakukan, dapat disimpulkan bahwa permasalahan utama dari berbagai masalah yang dihadapi terkait DAS Citarum di Desa Sindangpakuon adalah terkait dengan masalah pengolahan sampah. Permasalahan sampah ini dapat terjadi karena beberapa akar masalah yaitu: 1) kesadaran untuk membuang sampah pada tempatnya yang masih rendah, 2) ketersediaan Tempat Pembuangan Sementara (TPS) sampah Desa Sindangpakuon yang tidak memadai, 3) sampah kiriman dari wilayah lain. Masalah dan akar masalah pengolahan sampah ini sebagian ada yang terkait dengan tema lain, seperti misalnya terkait dengan konservasi air, sanitasi lingkungan, dan sedimentasi aliran sungai.

Dampak paling dekat dari permasalahan sampah yang tidak dibuang ketempat sebagaimana mestinya, khususnya apabila dibuang ke sungai adalah banjir. Pada beberapa wilayah di Desa Sindangpakuon kerap terjadi banjir apabila musim hujan sudah datang. Di Desa Sindangpakuon juga terjadi permasalahan konservasi air, yang disebabkan oleh masalah sampah yang mengotori aliran sungai, sehingga berkurangnya sumber air bersih untuk masyarakat dan sungai tidak bisa dimanfaatkan lagi untuk pemenuhan kebutuhan hidup masyarakat sehari-hari.

Permasalahan lain yang berhasil dianalisis yaitu terkait dengan erosi, sedimentasi, dan pencemaran air DAS Citarum di Desa Sindangpakuon. Berdasarkan hasil analisis diketahui beberapa akar masalah yang menyebabkan timbulnya permasalahan tersebut terdiri dari: 1) keberadaan pabrik tekstil yang sering kali diketemukan membuang limbah pabrik tidak dengan semestinya, 2) lokasi Desa Sindangpakuon yang dekat area pegunungan yang belum 
tertata dengan baik dan penebangan tidak dengan semestinya sehingga dapat menyebabkan erosi, 3) penumpukan sampah yang menyebabkan terjadinya sedimentasi sehingga menghambat aliran sungai tersebut.

Permasalahan terakhir terkait dengan sanitasi lingkungan, permasalahan sanitasi lingkungan yang terjadi di Desa Sindangpakuon yaitu kesulitan untuk mendapatkan air bersih. Berdasarkan analisis yang telah dilakukan, akar penyebab masalah tersebut adalah air sungai yang sudah tercemar akibat perilaku manusia yang kurang peduli dalam menjaga kebersihan air sungai. Salah satu contoh perilaku masyarakat tersebut adalah sering membuang sampah dan limbah baik limbah industri maupun MCK ke sungai.

\subsection{Perumusan Solusi Masalah}

Atas analisis permasalahan yang telah disusun pada bagian sebelumnya, penulis melakukan perumusan solusi untuk menanggulangi permasalahan-permasalahan yang dihadapi dalam bentuk desain program aksi. Desain program aksi disusun menyesuaikan kondisi masyarakat dan lingkungan di Desa Sindangpakuon. Berikut merupakan desain program aksi yang telah berhasil dibuat:

1) KERA OLAHRAGA (Keranjang Takakura Pengolah Sampah Organik Menjadi Kompos Organik). Berupa pelatihan pembuatan kompos keranjang Takakura bersamasama dengan masyarakat Desa Sindangpakuon.

2) JAJANG'S TAJIR (Jaring Ajaib Penangkap Sampah Anti Banjir). Merupakan upaya penjaringan sampah di aliran sungai yang bermanfaat untuk menampung sumbatan dan endapan sampah

3) PETE (Pengaman Tebing) Sungai. Program penanaman pohon di pinggir sungai dan membangun teras batu sebagai pengendali jurang dan ujung jurang dengan cara pemasangan batu spasi yang dibantu dengan bambu untuk menahan longsoran pada tebing dan memperbaiki lahan yang rusak.

4) BUDAK KERJA (Budidaya Ikan Nila Keramba Jaring Apung Desa Sindangpakuon). Merupakan upaya sistematis untuk pembersihan air sungai dan menjadikan sungai tersebut sebagai tempat budidaya ikan dengan membuat keramba sungai.

5) SETALI BERSIH (Septic Tank Komunal Penghasil Briket Dan Air Bersih). Merupakan produk inovasi teknologi berupa barang sebagai alat penyaring air pembuangan MCK dan alat pengolah limbah MCK menjadi briket. 


\section{Simpulan}

Penggunaan pendekatan active citizen dalam rangka pemetaan masalah terkait Daerah Aliran Sungai (DAS) Citarum di Desa Sindangpakuon telah terbukti dapat memberikan manfaat berupa analisis masalah secara komprehensif, sistematis, dan partisipatif dengan pendekatan dialog melibatkan sebanyak-banyaknya stakeholder sehingga tahapan analisis masalah sampai perumusan solusi penanggulangan masalah dapat menyentuh kepada akar permasalahan yang dihadapi. Dalam hal ini stakeholder yang dilibatkan dalam proses analisis permasalahan terkait Daerah Aliran Sungai (DAS) Citarum di Desa Sindangpakuon terdiri dari unsur masyarakat, pemerintah desa, aparat kepolisian dan TNI, Satgas Citarum Harum, dan unsur lainnya.

Sesuai dengan tujuan dasar dari metode active citizen, peran utama kegiatan analisis dan perumusan solusi diserahkan kepada mekanisme dialog dalam masyarakat dan mitra diskusi di dalam lingkungannya. Peran Dosen dan Mahasiswa dalam kegiatan KKN Tematik Citarum Harum di desa Sindangpakuon ini hanya sebagai fasilitator yang membantu menjembatani arah diskusi sehingga dapat lebih fokus.

Berdasarkan hasil analisis yang dilakukan terdapat beberapa akar masalah yang terkait dengan 5 topik pembahasan terkait masalah di Daerah Aliran Sungai (DAS) Citarum, diantara beberapa akar masalah tersebut diketahui akar masalah utama yang berhubungan dengan berbagai masalah yaitu terkait dengan masalah pengelolaan sampah. Akar permasalahan tersebut yang diharapkan dapat menjadi fokus prioritas perumusan solusi pemecahan masalah disamping solusi lainnya. Adapun rumusan desain masalah yang sudah dibuat terdiri dari 5 program yang terdiri dari: Kera Olahraga, Jajang’s Tajir, Pete Sungai, Budak Kerja, Setali Bersih.

\section{Daftar Pustaka}

BPS Jawa Barat. 2018. Provinsi Jawa Barat Dalam Angka: Jawa Barat Province in Figures. Bandung.

British Council. 2016. Active Citizens: Globally Connected, Locally Engaged. Annual Report. Pemerintah Provinsi Jawa Barat. 2019. Rencana Aksi Pengendalian Pencemaran dan Kerusakan DAS Citarum. Bandung.

Kementerian PPN/Bappenas. 2015. Roadmap 2015 Pengelolaan Sumber Daya Air Terpadu Wilayah Sungai Citarum. Jakarta. 
Lembaga Ilmu Pengetahuan Indonesia (LIPI). 2019. Citarum Harum dan Harapan Pemulihan Daerah Aliran Sungai. http://lipi.go.id/siaranpress/citarum-harum-dan-harapanpemulihan-daerah-aliran-sungai-/21575. Diakses 15 Nov 2019.

Universitas Padjadjaran. 2019. Konsep Penyelenggaraan KKN Citarum Harum Dengan Pendekatan Masyarakat Aktif. Sumedang.

Pemerintah Republik Indonesia. 2018. Peraturan Presiden Nomor 15 Tahun 2018 tentang Percepatan Pengendalian Pencemaran dan Kerusakan Daerah Aliran Sungai Citarum. Jakarta. 